\title{
Assessment of knowledge, attitude, and practice of child caregivers towards oral rehydration salt and zinc for the treatment of diarrhea in under 5 children in Gondar town
}

\author{
Dawit Kumilachew Yimenu ${ }^{a}$, Asmamaw Emagn Kasahun ${ }^{b}$, Mohammed Chane ${ }^{\text {a }}$, \\ Yeelshaddai Getachew ${ }^{a}$, Biruktawit Manaye ${ }^{a}$, Zemene Demelash Kifle ${ }^{c, "}$ \\ ${ }^{a}$ Department of Social Pharmacy, School of Pharmacy, College of Medicine and Health Sciences, University of Gondar, Gondar, Ethiopia \\ b Department of Pharmaceutics, School of Pharmacy, College of Medicine and Health Sciences, University of Gondar, Gondar, Ethiopia \\ ${ }^{\mathrm{c}}$ Department of Pharmacology, School of Pharmacy, College of Medicine and Health Sciences, University of Gondar, Gondar, Ethiopia
}

\section{A R T I C L E I N F O}

\section{Keywords:}

Attitude

Diarrhea

Knowledge

Oral rehydration salt

Practice

Zinc

\begin{abstract}
A B S T R A C T
Background: Diarrhea is the second-largest cause of death in under-five children, killing an estimated seven hundred sixty thousand children in Africa each year. This study aimed to assess the knowledge, attitude \& practice of child caregivers towards oral rehydration salt and zinc use for the treatment of diarrhea in under 5 children in Gondar town, Amhara regional state, Ethiopia.

Methods: Institutional based cross-sectional study was conducted at the pediatrics outpatient department of the University of Gondar comprehensive specialized hospital. Data was collected using a structured questionnaire and were entered and analyzed using Statistical Package for Social Sciences (SPSS) version 20. Frequencies and percentages were used to describe descriptive data and the results were presented using tables and figures. Both binary and multivariable logistic regression analyses were conducted to test for association between the different variables.

Results: A total of 306 caregivers were participated in the study. The majority of them $269(87.9 \%)$ defined diarrhea as the occurrence of watery or loose stool three and more times a day. Almost all caregivers but a few $297(97.1 \%$ ) believed that diarrhea is a series problem of childhood. Caregivers' educational level, occupational status, and sex were significant factors associated with their knowledge about Oral Rehydration Salt and zinc (P $\leq 0.05)$, while occupational status was the only significant factor associated with their attitude $(P \leq 0.05)$. Female caregivers were found 2.8 times more practical about Oral Rehydration Salt and zinc utilization for diarrheal management compared to male counterparts (AOR $=2.875(1.319,6.263)$ ). Similarly, employed caregivers were 2.9 times more to have good practice than unemployed caregivers (AOR $=2.927(1.533,5.587)$. Conclusion: There was good knowledge, attitude, and practice about Oral Rehydration Salt and zinc consumption among child caregivers in Gondar. Regular educational strategies aimed at improving child caregivers' awareness of diarrhea disease management and utilization of Oral Rehydration Salt and Zinc tablets are advised.
\end{abstract}

\section{Background}

Diarrhea is defined as, "the passage of three or more loose or liquid stools per day (or more frequent passage than is normal for the individual)", ${ }^{1,2}$ It can be acute or chronic, and blood may be present, as in dysentery. Diarrhea can be caused by a variety of reasons, including bacterial, protozoal, and viral illnesses, such as rotavirus, cholera, and typhoid enteritis, all of which are transmitted by the fecal-oral route. It could also be non-infectious, such as food indiscretions or digestive issues and problems of mal-digestion and mal-absorption. ${ }^{3}$

Diarrheal disease (DD) is still a major public health issue around the world, coming in second only to pneumonia as a cause of death in children under the age of five. Approximately 1.5 million people die each year as a result of it all over the world. ${ }^{4}$ It is also the leading cause of death among children in Ethiopia. Diarrheal illness affects $13.3 \%$ of children under the age of five, according to the EDHS 2012. In 2007,

\footnotetext{
* Corresponding author. Department of Pharmacology, School of Pharmacy, College of Medicine and Health Sciences, University of Gondar, P.O. Box: 196, Gondar, Ethiopia.

E-mail address: zeme2010@gmail.com (Z.D. Kifle).
} 
Ethiopia's child mortality rate was 199 per 1000 live births, or around one out of every five deaths. It's treatable as well as preventable. ${ }^{5}$

Rehydration using oral rehydration salts (ORS) solution is an important part of treating diarrhea. ${ }^{6}$ During episodes of diarrhea, rehydration therapy is an essential step to save children's lives. Every year, however, millions of children die as a result of a failure to adequately replace the fluid. Oral rehydration therapy (ORT) for diarrhea could prevent over 1.5 million fatalities per year or $15 \%$ of all deaths in children under the age of five. ${ }^{7}$ Diarrhea morbidity and mortality can be reduced with proper home management. Dehydration owing to a loss of fluids and electrolytes is thought to be the cause of $60-70 \%$ of diarrhea-related deaths. Knowledge of the causes of diarrhea and the accompanying warning indicators among caregivers, as well as the prevention of dehydration during diarrheal episodes through the use of Oral Rehydration Salts, are all important factors. ${ }^{8,9}$

In developing countries, diarrheal illnesses remained the second leading cause of death in children under the age of five. Diarrhea is also a major killer of children in Ethiopia, making it a severe public health issue. Every year, an estimated 73,700 children under the age of five years die because of diarrhea. ${ }^{10}$

Oral Rehydration Salts solution and zinc uses a component of child survival strategy. However, available studies and information provided limited or inadequate knowledge to increase Oral Rehydration Salts solution and zinc use. This is study will provide information on determinants of Oral Rehydration Salts solution and zinc use aimed at guiding health providers \& policymakers in improving childhood morbidities and mortalities due to diarrhea. Thus, this study aimed to assess the knowledge, attitude \& practice of child caregivers towards oral rehydration salt and zinc use for the treatment of diarrhea in under 5 children in Gondar town, Amhara regional state, Ethiopia.

\section{Method and materials}

\subsection{Study design, period, and area}

A descriptive study was conducted at the university of Gondar comprehensive specialized hospital. The hospital is located in Gondar city, North West Ethiopia. It is located $737 \mathrm{~km}$ away from the capital city of Ethiopia. It is one of the most prestigious hospitals in the country currently serving about seven million people in the catchment area. The study was conducted from August 07/2021 to September 10/2021.

Source population: All caregivers living in Gondar town having under 5 children.

Study population: All under-five child caregivers in Gondar town that fulfill the inclusion criteria.

Inclusion and Exclusion criteria: The inclusion criteria includes those under-five child caregivers in Gondar town that presented to the pediatric outpatient department of the University of Gondar specialized hospital during the study period, and those volunteers to participate in the study. However, the exclusion criteria include those under-five child caregivers that were unable to communicate freely with the data collectors due to medical conditions and/or language barriers.

\subsection{Sample size determination}

The sample size was calculated by using single population proportion formula with the following assumption. Prevalence of caregiver's knowledge of ORS $74.4 \%$, based on the finding of a study conducted in Wolaita Sodo town in $2016,{ }^{11}$ the margin of error of $5 \%$, and confidence interval of $95 \%$.

$\mathrm{n}=(\mathrm{Z} \alpha / 2) 2 \mathrm{P}(1-\mathrm{P}) / \mathrm{d} 2$

Where, $\mathrm{n}=$ the sample size, $\mathrm{Z}=$ Critical value $=1.96, \mathrm{P}=$ Prevalence $=$ $74.4 \%, d=$ Margin of error $=5 \%$

$\mathrm{n}=(1.96) 2 \times 0.744(1-0.744) /(0.05) 2=292$
By adding a non-response rate of $5 \%$ the final sample size was 306 .

\subsection{Data collection methods and procedure}

A structured, interviewer-administered questionnaire was used for data collection. The questionnaire was adapted from previous studies and modified to fit the current study setup ${ }^{11-14}$ First, the English version of the questionnaire was prepared. Then it has been translated to the Amharic version (local language) then back to English. The questionnaire consisted of four parts. The first part contains questions about the socio-demographic characteristics of caregivers and their dependents. The second part consisted of eleven questions to assess the knowledge of the participants. The third and fourth parts consist of six and nineteen questions to assess the attitude and practice of the study participants.

Dependent variables: Knowledge, Attitude, and Practice of the child caregivers on ORS and Zinc utilization.

Independent variables: Caregiver's factors (Sociodemographic and work-related characteristic; age, sex, level of education, marital status, religion, occupation etc ...), Child related factors (Demographic characteristics; age of the child, breastfeeding, sex, number of under-five children etc ....), Other factors (Partner's occupation, educational status, income etc ...).

\subsection{Operational definition of terms}

- Caregiver: A person who is responsible for a child.

- Diarrhea: the passage of three or more loose or liquid stools per day

- Dehydration: the loss of water from the body, as a result of diarrhea.

- Good attitude: who answer above the mean of the attitude question was considered as having a good attitude.

- Good knowledge: who answer above the mean of the Knowledge question was considered as having good knowledge.

- Good practice: who able to answer above the mean of the practice question was considered as having good practice

- Oral Rehydration Therapy (ORT): administration of recommended fluid by mouth to prevent or correct dehydration as a result of diarrhea.

- Oral Rehydration Salt (ORS): A Solution used for the replacement of water secondary to diarrhea.

- Poor attitude: who answer below the mean of the attitude question was considered as poor attitude.

- Poor knowledge: who answer below the mean of the knowledge question was considered as poor knowledge.

- Poor practice: who answer below the mean of the practice questions was considered as Poor practice.

- Rehydration: replacement of fluid.

\subsection{Data quality management}

To ensure the quality of the data the following activities were undertaken: careful design, translation, and retranslation of the questionnaire, close supervision of the data collection procedures, proper categorization and coding of the data, reviewing the collected data for accuracy and completeness by data collectors and supervisors, and by checking the recorded data. A pre-test of the questionnaire was also conducted on $5 \%$ of the total sample size before the actual data collection, and necessary amendments were made based on the feedback. The participants in the pre-test were excluded from the final study.

\subsection{Data analysis}

After data collection, each questionnaire was checked for completeness and consistency by data collectors. The collected data were entered and analyzed using Statistical Package for Social Sciences (SPSS) version 20. Frequencies and percentages were used to describe descriptive data and the results were presented using tables and figures. 
Table 1

Distribution of socio-demographic variables of the study participants (caregivers and children).

\begin{tabular}{|c|c|c|c|}
\hline Variable & Category & $\begin{array}{l}\text { Frequency } \\
(\mathrm{N}=306)\end{array}$ & $\begin{array}{l}\text { Percentage } \\
\%\end{array}$ \\
\hline \multirow[t]{2}{*}{ Sex } & Male & 50 & 16.3 \\
\hline & Female & 256 & 83.7 \\
\hline \multirow[t]{3}{*}{ Age of caregiver in years } & $15-24$ & 32 & 10.5 \\
\hline & $24-35$ & 212 & 69.3 \\
\hline & $>35$ & 62 & 20.3 \\
\hline \multirow[t]{5}{*}{ Religion } & Orthodox & 238 & 77.8 \\
\hline & Muslim & 54 & 17.6 \\
\hline & Catholic & 0 & 0 \\
\hline & Protestant & 12 & 3.9 \\
\hline & Other $^{\mathrm{a}}$ & 2 & 0.7 \\
\hline \multirow[t]{4}{*}{ Level of education } & $\begin{array}{l}\text { No formal } \\
\text { education }\end{array}$ & 10 & 3.3 \\
\hline & Primary school & 58 & 19.0 \\
\hline & $\begin{array}{l}\text { Secondary school } \\
(9-12)\end{array}$ & 108 & 35.3 \\
\hline & $\begin{array}{l}\text { Higher education/ } \\
\text { university/college }\end{array}$ & 130 & 42.5 \\
\hline \multirow[t]{2}{*}{ Residence } & Rural & 30 & 9.8 \\
\hline & Urban & 276 & 90.2 \\
\hline \multirow{3}{*}{ Occupational status } & Employed & 160 & 52.3 \\
\hline & $\begin{array}{l}\text { Searching for job/ } \\
\text { unemployed }\end{array}$ & 29 & 9.5 \\
\hline & House wife & 117 & 38.2 \\
\hline \multirow[t]{2}{*}{ Type of occupation } & Health worker & 12 & 3.9 \\
\hline & Non health worker & 148 & 48.4 \\
\hline \multirow{4}{*}{ Marital status: } & Single & 8 & 2.6 \\
\hline & Married & 286 & 93.5 \\
\hline & Divorced & 7 & 2.3 \\
\hline & Widowed & 5 & 1.6 \\
\hline \multirow[t]{5}{*}{$\begin{array}{l}\text { If married, what does your } \\
\text { husband/wife do? }\end{array}$} & $\begin{array}{l}\text { Governmental } \\
\text { employee }\end{array}$ & 114 & 37.3 \\
\hline & Private employ & 83 & 27.1 \\
\hline & Merchant & 55 & 18.0 \\
\hline & House wife & 15 & 4.9 \\
\hline & Other $^{\mathrm{b}}$ & 19 & 6.2 \\
\hline \multirow{4}{*}{$\begin{array}{l}\text { What is the highest level of } \\
\text { education he/she has } \\
\text { attained? }\end{array}$} & $\begin{array}{l}\text { No formal } \\
\text { education }\end{array}$ & 7 & 2.3 \\
\hline & Primary school & 30 & 9.8 \\
\hline & $\begin{array}{l}\text { Secondary school } \\
(9-12)\end{array}$ & 85 & 27.8 \\
\hline & $\begin{array}{l}\text { Higher education/ } \\
\text { university/college }\end{array}$ & 164 & 53.6 \\
\hline \multirow[t]{2}{*}{ Type of profession } & Health worker & 21 & 6.9 \\
\hline & Non health worker & 265 & 86.6 \\
\hline \multirow[t]{4}{*}{ Monthly income } & $<1000$ & 6 & 2.0 \\
\hline & $1000-30000$ & 60 & 19.6 \\
\hline & $3000-5000$ & 70 & 22.9 \\
\hline & $>5000$ & 170 & 55.6 \\
\hline \multirow[t]{3}{*}{ Family size } & $<$ or equal to 3 & 77 & 25.2 \\
\hline & 4 to 5 & 184 & 60.1 \\
\hline & $>5$ & 45 & 14.7 \\
\hline \multirow{4}{*}{$\begin{array}{l}\text { Relation of caregiver to the } \\
\text { child }\end{array}$} & Mother & 245 & 80.1 \\
\hline & Father & 47 & 15.4 \\
\hline & Sister/brother & 3 & 1.0 \\
\hline & Grandparent & 9 & 2.9 \\
\hline \multirow[t]{5}{*}{ Age of child } & 0-11 month & 15 & 4.9 \\
\hline & $12-23$ month & 47 & 15.4 \\
\hline & 24-35 month & 58 & 19.0 \\
\hline & 36-47 month & 95 & 31.0 \\
\hline & 48-59 month & 91 & 29.7 \\
\hline Sex of child & Male & 163 & 53.3 \\
\hline & Female & 143 & 47.7 \\
\hline For how long was your & Less than 6 months & 49 & 16.0 \\
\hline child on exclusive & 6 months & 248 & 81.0 \\
\hline breastfeeding & $\begin{array}{l}\text { Greater than } 6 \\
\text { months }\end{array}$ & 9 & 2.9 \\
\hline Is your child currently & Yes & 84 & 27.5 \\
\hline breastfeeding? & No & 222 & 72.5 \\
\hline How many children under & 1 & 206 & 67.3 \\
\hline five do you have in your & 2 & 99 & 32.4 \\
\hline house? & 3 and above & 1 & 0.3 \\
\hline & Yes & 293 & 95.8 \\
\hline
\end{tabular}

Table 1 (continued)

\begin{tabular}{|c|c|c|c|}
\hline Variable & Category & $\begin{array}{l}\text { Frequency } \\
(\mathrm{N}=306)\end{array}$ & $\begin{array}{l}\text { Percentage } \\
\%\end{array}$ \\
\hline \multirow{2}{*}{$\begin{array}{l}\text { Does all of your children } \\
\text { fully vaccinated? }\end{array}$} & No & 13 & 4.2 \\
\hline & Other & 2 & 0.7 \\
\hline \multirow{4}{*}{$\begin{array}{l}\text { Where do you take your } \\
\text { child whenever s/he/ } \\
\text { they get diarrhea? }\end{array}$} & To health institution & 305 & 99.7 \\
\hline & Traditional healer & 1 & 0.3 \\
\hline & $\begin{array}{l}\text { Didn't take s/he/ } \\
\text { them to anywhere }\end{array}$ & - & - \\
\hline & Other & - & - \\
\hline \multirow{2}{*}{$\begin{array}{l}\text { Do you have health } \\
\text { insurance? }\end{array}$} & Yes & 91 & 29.7 \\
\hline & No & 215 & 70.3 \\
\hline \multirow{2}{*}{$\begin{array}{l}\text { Did your child get diarrhea } \\
\text { in the last two weeks? }\end{array}$} & Yes & 76 & 24.8 \\
\hline & No & 230 & 75.2 \\
\hline \multirow{2}{*}{$\begin{array}{l}\text { Did your child receive ORS } \\
\text { solution in the last two } \\
\text { weeks? }\end{array}$} & Yes & 62 & 20.3 \\
\hline & No & 244 & 79.7 \\
\hline
\end{tabular}

Both binary and multivariable logistic regression analyses were conducted to test for association between the different variables and a Pvalue of $\leq 0.05$ was used to declare statistical significance at $95 \%$ Confidence Interval (CI).

\section{Result}

A total of 306 caregivers were participated in the study. The mean age of the caregivers was 31.5 [SD \pm 7.4$]$ and more than two-thirds of them $212(69.3 \%)$ were found to be between 25 and 35 years. Of the total caregivers, $256(83.7 \%)$ of them were females and 238 (77.8\%) of them were Orthodox in Religion. About 296 (96.7\%) of the participants have had a formal education in which 130 (42.5\%) have a higher educational status. The majority of the caregivers 160 (53.3\%) were employed and more than $90 \%$ of them were urban residents (Table 1 ).

Concerning partner's sociodemographic status, 164 (53.6\%) of the caregivers reported that their partners have higher degree educational level (diploma/degree and above level). In occupational status of spouses, $114(37.3 \%)$ were public servants followed by $83(27.1 \%)$ of them being private employees. Among the employed spouses, 21(6.9\%) were health workers. More than half of the caregivers 170 (55.6\%) earn above 5000-birr monthly income and the majority of households 184 $(60.1 \%)$ of were a family of four and five (Table 1 ).

The age of the children ranges from 0 to 59 months with a mean of 2.7 years $[\mathrm{SD} \pm 1.21]$ and the majority $95(31.0 \%)$ were between 36 and 47 months followed by 91 (29.7\%) between 48 and 59 months. The majority of the children were males $163(53.3 \%)$. Most of the children 293(95.8\%) were fully vaccinated and $248(81.0 \%)$ were exclusively fed breast milk for six months (Table 1 ).

\subsection{Knowledge of caregivers about diarrhea and its management}

The majority of the participants 269 (87.9\%) defined diarrhea as occurring when the stool was watery or lose more than three or more times and 21 (6.9\%) participants indicated diarrhea as the presence of blood. Most caregivers 297(97.1\%) believed that diarrhea as a series problem of childhood illness and 268(87.6\%) knew the danger signs related to childhood diarrhea. About 257 (84.0\%) of caregivers had awareness about different causes of acute diarrhea in which $219(71.6 \%)$ reported it as caused by poor hygiene.

More than half of caregivers 157(51.3\%) said ORS should be started soon after the first/second motion of watery stool noticed, followed by $118(38.6 \%)$ reported to be started after two days of watery stool. Almost half of caregivers 151(49.3) said ORS should be administered after each bowel motion and 113(36.9\%) reported every hour (Table 2).

All study participants reported that they have heard about ORT packet, but only 242(79.1\%) were answered correctly for replacement of 
Table 2

Knowledge of caregivers about ORS and zinc usage for diarrheal disease management for under-five children in Gondar town, Amhara regional state, North West Ethiopia, 2021.

\begin{tabular}{|c|c|c|c|}
\hline Variable & Category & $\begin{array}{l}\text { Frequency } \\
(\mathrm{N}=306)\end{array}$ & $\begin{array}{l}\text { Percentage } \\
\%\end{array}$ \\
\hline \multirow[t]{6}{*}{$\begin{array}{l}\text { What do you understand } \\
\text { by diarrhea? }\end{array}$} & $\begin{array}{l}\text { Frequent passing of } \\
\text { watery stool ( } 3 \text { or more } \\
\text { times) }\end{array}$ & 269 & 87.9 \\
\hline & $\begin{array}{l}\text { Frequent passing of } \\
\text { non- watery stool }\end{array}$ & 6 & 2.0 \\
\hline & Blood in stools & 21 & 6.9 \\
\hline & Greenish stools & 7 & 2.3 \\
\hline & Mucus in stool & 3 & 1.0 \\
\hline & Other, specified & - & - \\
\hline \multirow{2}{*}{$\begin{array}{l}\text { Do you think diarrhea is } \\
\text { a serious child illness? }\end{array}$} & Yes & 297 & 97.1 \\
\hline & No & 9 & 2.9 \\
\hline \multirow{6}{*}{$\begin{array}{l}\text { What do you think are } \\
\text { the causes of diarrhea? }\end{array}$} & Poor hygiene & 219 & 71.6 \\
\hline & $\begin{array}{l}\text { Food poisoning/ } \\
\text { contaminated food }\end{array}$ & 242 & 79.1 \\
\hline & Contaminated water & 201 & 65.7 \\
\hline & Teething & 49 & 16.0 \\
\hline & Intestinal parasite & 19 & 6.2 \\
\hline & Other $^{\mathrm{a}}$ & 2 & 0.7 \\
\hline \multirow{2}{*}{$\begin{array}{l}\text { Do you know any danger } \\
\text { signs related to } \\
\text { diarrhea in a child? }\end{array}$} & Yes & 268 & 87.6 \\
\hline & No & 38 & 12.4 \\
\hline \multirow{7}{*}{$\begin{array}{l}\text { What are some of the } \\
\text { danger signs } \\
\text { associated with } \\
\text { diarrhea? }\end{array}$} & $\begin{array}{l}\text { Becoming weak or } \\
\text { lethargic frequent } \\
\text { passing of diarrhea }\end{array}$ & 218 & 76.8 \\
\hline & $\begin{array}{l}\text { Repeated vomiting/ } \\
\text { vomiting everywhere }\end{array}$ & 107 & 37.7 \\
\hline & $\begin{array}{l}\text { Fever and blood in } \\
\text { stool }\end{array}$ & 154 & 54.2 \\
\hline & Marked thirst of water & 53 & 18.7 \\
\hline & Poor feeding & 88 & 31.0 \\
\hline & Reduced urine output & 13 & 4.6 \\
\hline & Other $^{\mathrm{b}}$ & 8 & 2.8 \\
\hline \multirow{2}{*}{$\begin{array}{l}\text { Do you think diarrhea is } \\
\text { Preventable? }\end{array}$} & Yes & 291 & 95.1 \\
\hline & No & 15 & 4.9 \\
\hline \multirow[t]{5}{*}{ The Purpose of ORS is? } & To Stop diarrhea & 53 & 17.3 \\
\hline & $\begin{array}{l}\text { Reduce the duration of } \\
\text { Diarrhea }\end{array}$ & 9 & 2.9 \\
\hline & $\begin{array}{l}\text { Replace the body salts, } \\
\text { energy and water lost } \\
\text { in diarrhea }\end{array}$ & 242 & 79.1 \\
\hline & Prevents diarrhea & 2 & 0.7 \\
\hline & I do not know & - & - \\
\hline \multirow[t]{4}{*}{ ORS is given with: } & Feeding bottle & 49 & 16.0 \\
\hline & Cup and spoon & 243 & 79.4 \\
\hline & Other ${ }^{c}$ & 14 & 4.6 \\
\hline & I do not now & - & - \\
\hline \multirow[t]{4}{*}{$\begin{array}{l}\text { How soon should the use } \\
\text { of ORS Start? }\end{array}$} & $\begin{array}{l}\text { After two days of } \\
\text { watery stool }\end{array}$ & 118 & 38.6 \\
\hline & $\begin{array}{l}\text { After three days of } \\
\text { watery stool }\end{array}$ & 26 & 8.5 \\
\hline & $\begin{array}{l}\text { Soon after the first/ } \\
\text { second motion of } \\
\text { watery stool noticed }\end{array}$ & 157 & 51.3 \\
\hline & I do not know & 5 & 1.6 \\
\hline \multirow{5}{*}{$\begin{array}{l}\text { Timing of ORS } \\
\text { administration: It is } \\
\text { given }\end{array}$} & Every hour & 113 & 36.9 \\
\hline & $\begin{array}{l}\text { After each bowel } \\
\text { motion }\end{array}$ & 151 & 49.3 \\
\hline & After vomiting & 21 & 6.9 \\
\hline & $\begin{array}{l}\text { To prevent diarrhea } \\
\text { before it starts }\end{array}$ & 16 & 5.2 \\
\hline & I don't know & 5 & 1.6 \\
\hline \multirow{2}{*}{$\begin{array}{l}\text { Have you ever heard } \\
\text { about zinc? }\end{array}$} & Yes & 226 & 73.9 \\
\hline & No & 80 & 26.1 \\
\hline \multirow[t]{5}{*}{ The purpose of zinc is? } & $\begin{array}{l}\text { Doesn't have any } \\
\text { purpose }\end{array}$ & 9 & 2.9 \\
\hline & $\begin{array}{l}\text { To decrease the } \\
\text { diarrhea }\end{array}$ & 158 & 51.6 \\
\hline & $\begin{array}{l}\text { To prevent } \\
\text { dehydration }\end{array}$ & 45 & 14.7 \\
\hline & No idea & 92 & 30.1 \\
\hline & Other & 2 & 0.7 \\
\hline
\end{tabular}

3.3. Diarrhea management practice of child care-givers

Of the total participants, 295(96.4\%) had ever experienced ORS use, and 206(67.3\%) participants had experienced zinc use. In addition, 190 $(44.0 \%)$ of caregivers had the practice of giving rice water to their child with diarrhea, and $90(20.8 \%)$ of the caregivers had the practice of giving salt and sugar solution. Among those who ever used ORS, 290 (94.8\%) have the practice to use ORS only for $24 \mathrm{~h}$ once after it is reconstituted.

About 288(94.1\%) of caregivers prepared ORS correctly by adding one ORS sachet to $1000 \mathrm{ml}$ of water while. The majority of the respondents $102(33.3 \%)$ used previously boiled and cooled water to prepare ORS solution, while $190(62.1 \%)$ use highland water. After reconstitution, only 99 (32.4\%) of caregivers gave the solution after the passage of every loose stool, while most of them 147(48.0\%) gave six and above times per day. (Fig. 2)

One hundred eighty-one (59.2\%) respondents gave zinc per day and $117(38.2 \%)$ administer it correctly for 10-14 days. More than half 163 (53.3\%) of caregivers stored ORS Sacket/zinc tablet on a shelf followed by $82(26.8 \%)$ inside a bag or an object. Most of the participants reported that they dispose of unused ORS Sacket 245(80.1\%) and zinc tablet 226 $(73.9 \%)$ in the waste disposal area. (Table 3)

Of the total 306 caregivers, 199(65\%) of them had good knowledge, and $257(84.0 \%)$ them had a good attitude about the management of diarrhea and use of ORS and zinc. In addition, 187 (61.1\%) of them were found to have good practice of diarrhea management and ORS/Zinc 
Table 3

Practice of under-five child caregivers towards diarrheal disease management using ORS and zinc in Gondar town, Amhara region, North West Ethiopia, 2021.

\begin{tabular}{|c|c|c|c|}
\hline Variable & Category & $\begin{array}{l}\text { Frequency } \\
(306)\end{array}$ & $\begin{array}{l}\text { Percentage } \\
\%\end{array}$ \\
\hline \multirow{6}{*}{$\begin{array}{l}\text { What do you feed your } \\
\text { child on diarrhea? }\end{array}$} & Breast milk only & 14 & 4.6 \\
\hline & $\begin{array}{l}\text { Breast milk }+ \text { infant } \\
\text { formula }\end{array}$ & 25 & 8.2 \\
\hline & $\begin{array}{l}\text { Complementary } \\
\text { feeding only }\end{array}$ & 152 & 49.7 \\
\hline & $\begin{array}{l}\text { Complementary } \\
\text { feeding plus breast milk }\end{array}$ & 99 & 32.4 \\
\hline & Normal family diet & 15 & 4.9 \\
\hline & Other $^{\mathrm{a}}$ & 1 & 0.3 \\
\hline \multirow{2}{*}{$\begin{array}{l}\text { Have you ever given oral } \\
\text { rehydration salt to your } \\
\text { child? }\end{array}$} & Yes & 295 & 96.4 \\
\hline & No & 11 & 3.6 \\
\hline \multirow{2}{*}{$\begin{array}{l}\text { Have you ever given Zinc } \\
\text { to your child? }\end{array}$} & Yes & 206 & 67.3 \\
\hline & No & 100 & 32.7 \\
\hline \multirow{7}{*}{$\begin{array}{l}\text { What type of home-made } \\
\text { oral solution do you } \\
\text { give to your child with } \\
\text { diarrhea? }\end{array}$} & Sugar and salt solution & 90 & 20.8 \\
\hline & Salt with water & 5 & 1.2 \\
\hline & Juice & 29 & 6.7 \\
\hline & Soup & 59 & 13.7 \\
\hline & Rice water & 190 & 44.0 \\
\hline & Other ${ }^{\mathrm{b}}$ & 5 & 1.2 \\
\hline & I do not give anything & 54 & 12.5 \\
\hline \multirow{5}{*}{$\begin{array}{l}\text { After how long the } \\
\text { diarrhea started do you } \\
\text { give ORS and zinc to } \\
\text { your child? }\end{array}$} & The same day & 134 & 43.8 \\
\hline & Second day & 142 & 46.4 \\
\hline & Third day & 14 & 4.6 \\
\hline & Fourth day & 2 & 0.7 \\
\hline & I do not know & 14 & 4.6 \\
\hline \multirow[t]{6}{*}{$\begin{array}{l}\text { How do you prepare } \\
\text { ORS? }\end{array}$} & $\begin{array}{l}1 \text { sachet of ORS }-300 \\
\text { mls ( } 3 \text { coke bottle) of } \\
\text { water }\end{array}$ & 2 & 0.7 \\
\hline & $\begin{array}{l}1 \text { sachet of ORS }-500 \\
\text { mls ( } 1 \text { small size of } \\
\text { mineral bottle) }\end{array}$ & 10 & 3.3 \\
\hline & $\begin{array}{l}1 \text { sachet of ORS }-750 \\
\text { mls ( } 1 \text { medium size of } \\
\text { mineral bottle) }\end{array}$ & 2 & 0.7 \\
\hline & $\begin{array}{l}1 \text { sachet of ORS } \\
-1000 \mathrm{mls} \text { ( } 1 \mathrm{~L} \text { of water) }\end{array}$ & 288 & 94.1 \\
\hline & $\begin{array}{l}1 \text { sachet of ORS } \\
-1500 \mathrm{mls}(1.5 \mathrm{~L} \text { or large } \\
\text { size of mineral of } \\
\text { water) }\end{array}$ & 1 & 0.3 \\
\hline & Other preparation ${ }^{\mathrm{s}}$ & 3 & 1.0 \\
\hline \multirow{5}{*}{$\begin{array}{l}\text { Who taught you how to } \\
\text { mix ORS solutions and } \\
\text { how to administer } \\
\text { zinc? }\end{array}$} & $\begin{array}{l}\text { Friend/neighbor/ } \\
\text { relative }\end{array}$ & 14 & 4.6 \\
\hline & Health provider & 266 & 86.9 \\
\hline & Media & 8 & 2.6 \\
\hline & Read instruction myself & 17 & 5.6 \\
\hline & Other $^{c}$ & 1 & 0.3 \\
\hline \multirow{6}{*}{$\begin{array}{l}\text { How often should ORS be } \\
\text { given? }\end{array}$} & Once a day & 8 & 2.6 \\
\hline & $2-3$ times a day & 24 & 7.8 \\
\hline & 4-5 times a day & 22 & 7.2 \\
\hline & $6 \&$ above times a day & 147 & 48.0 \\
\hline & $\begin{array}{l}\text { After the passing of } \\
\text { every loose stool }\end{array}$ & 99 & 32.4 \\
\hline & No idea & 6 & 2.0 \\
\hline \multirow{4}{*}{$\begin{array}{l}\text { How much ORS solution } \\
\text { should be given to a } \\
\text { child with diarrhea? }\end{array}$} & $\begin{array}{l}\text { As much as s/he can } \\
\text { drink }\end{array}$ & 279 & 91.2 \\
\hline & Coffee cup of $100 \mathrm{ml}$ & 10 & 3.3 \\
\hline & $\begin{array}{l}\text { Don't know/can't } \\
\text { answer }\end{array}$ & 17 & 5.6 \\
\hline & Other (specify) & - & - \\
\hline \multirow{4}{*}{$\begin{array}{l}\text { How long should the } \\
\text { mixed ORS last? }\end{array}$} & $24 \mathrm{~h}$. & 290 & 94.8 \\
\hline & $48 \mathrm{~h}$. & 1 & 0.3 \\
\hline & $72 \mathrm{~h}$. & 4 & 1.3 \\
\hline & Other $^{\mathrm{d}}$ & 11 & 3.6 \\
\hline \multirow[t]{4}{*}{$\begin{array}{l}\text { What water do you use to } \\
\text { mix ORS solution? }\end{array}$} & $\begin{array}{l}\text { Previously boiled and } \\
\text { cooled water }\end{array}$ & 102 & 33.3 \\
\hline & Drinking water & 13 & 4.2 \\
\hline & Any available water & 1 & 0.3 \\
\hline & Highland water & 190 & 62.1 \\
\hline \multirow[t]{2}{*}{ Zinc is given } & Daily & 181 & 59.2 \\
\hline & Twice daily & 16 & 5.2 \\
\hline
\end{tabular}

Table 3 (continued)

\begin{tabular}{|c|c|c|c|}
\hline Variable & Category & $\begin{array}{l}\text { Frequency } \\
(306)\end{array}$ & $\begin{array}{l}\text { Percentage } \\
\%\end{array}$ \\
\hline \multirow{9}{*}{$\begin{array}{l}\text { Zinc is given for the } \\
\text { duration of }\end{array}$} & Three times daily & 10 & 3.3 \\
\hline & Four times daily & 3 & 1.0 \\
\hline & I do not know & 96 & 31.4 \\
\hline & Three days & 21 & 6.9 \\
\hline & Five days & 38 & 12.4 \\
\hline & Seven days & 28 & 9.2 \\
\hline & 10-14 days & 117 & 38.2 \\
\hline & Other $^{\mathrm{e}}$ & 5 & 1.6 \\
\hline & I do not know & 97 & 31.7 \\
\hline \multirow{3}{*}{$\begin{array}{l}\text { Do you think ORS price is } \\
\text { expensive }\end{array}$} & Yes & 20 & 6.5 \\
\hline & No & 260 & 85.0 \\
\hline & I do not know & 26 & 8.5 \\
\hline \multirow{5}{*}{$\begin{array}{l}\text { Where did you store the } \\
\text { ORS sachet and Zinc } \\
\text { tablet at home? }\end{array}$} & Inside refrigerator & 24 & 7.8 \\
\hline & Shelf & 163 & 53.3 \\
\hline & Inside the bag/object & 82 & 26.8 \\
\hline & on the table & 31 & 10.1 \\
\hline & Other $^{\mathrm{f}}$ & 6 & 2.0 \\
\hline \multirow{2}{*}{$\begin{array}{l}\text { Did you check/request } \\
\text { the expiry date for the } \\
\text { ORS and zinc tablet } \\
\text { you purchased? }\end{array}$} & Yes & 219 & 71.6 \\
\hline & No & 87 & 28.4 \\
\hline \multirow[b]{2}{*}{$\begin{array}{l}\text { Did you request for } \\
\text { information regarding } \\
\text { the use of ORS and zinc } \\
\text { tablet from a health } \\
\text { professional/ } \\
\text { pharmacist whenever } \\
\text { you purchased these } \\
\text { products }\end{array}$} & Yes & 285 & 93.1 \\
\hline & No & 21 & 6.9 \\
\hline \multirow{6}{*}{$\begin{array}{l}\text { Where do you disposed } \\
\text { unused ORS solution/ } \\
\text { sachet? }\end{array}$} & Waste disposal area & 245 & 80.1 \\
\hline & Toilet & 31 & 10.1 \\
\hline & Under the ground & 6 & 2.0 \\
\hline & Outside the compound & 4 & 1.3 \\
\hline & Burn & 4 & 1.3 \\
\hline & Other $^{g}$ & 16 & 5.2 \\
\hline \multirow{6}{*}{$\begin{array}{l}\text { Where do you disposed } \\
\text { unused zinc tablets? }\end{array}$} & Waste disposal area & 226 & 73.9 \\
\hline & Toilet & 26 & 8.5 \\
\hline & Under the ground & 6 & 2.0 \\
\hline & Outside the compound & 4 & 1.3 \\
\hline & Burn & 6 & 2.0 \\
\hline & Other $^{g}$ & 38 & 12.4 \\
\hline
\end{tabular}

ORS: Oral Rehydration Salt.

c prepare it with 2-L water.

a will not give any food.

b Lemon, water and salt solution.

c I'm health professional.

d More than $72 \mathrm{~h}$.

e 1day, 2 day.

${ }^{f}$ Drawer, Drug box.

g I will use it again.

utilization (Fig. 3).

\subsection{Factors associated with caregivers knowledge towards ORS and zinc use in under-five children}

In the bivariate analysis, a significant association was observed between the educational status of caregivers and their knowledge about ORS and zinc utilization for diarrheal disease case management. Highly educated (university, college) caregivers were 13.3 times more likely to have knowledge about ORS and zinc utilization than those who were not had formal education. ( $C O R=13.3(2.686,66.193)$ ). Caregiver's occupational status was among the socio-economic factors which were significantly associated with the knowledge of ORS and zinc usage on diarrheal disease case management. Caregivers with occupational status of employed were 2.949 times more likely knowledgeable about ORS and zinc utilization than those who were housewives. (COR $=2.949$ $(1.759,4.943))$. Caregivers with a monthly income of 3000-5000 were also found 14.444 times more likely knowledgeable about ORS and zinc utilization than those who were housewives (COR $=14.444(1.580$, 


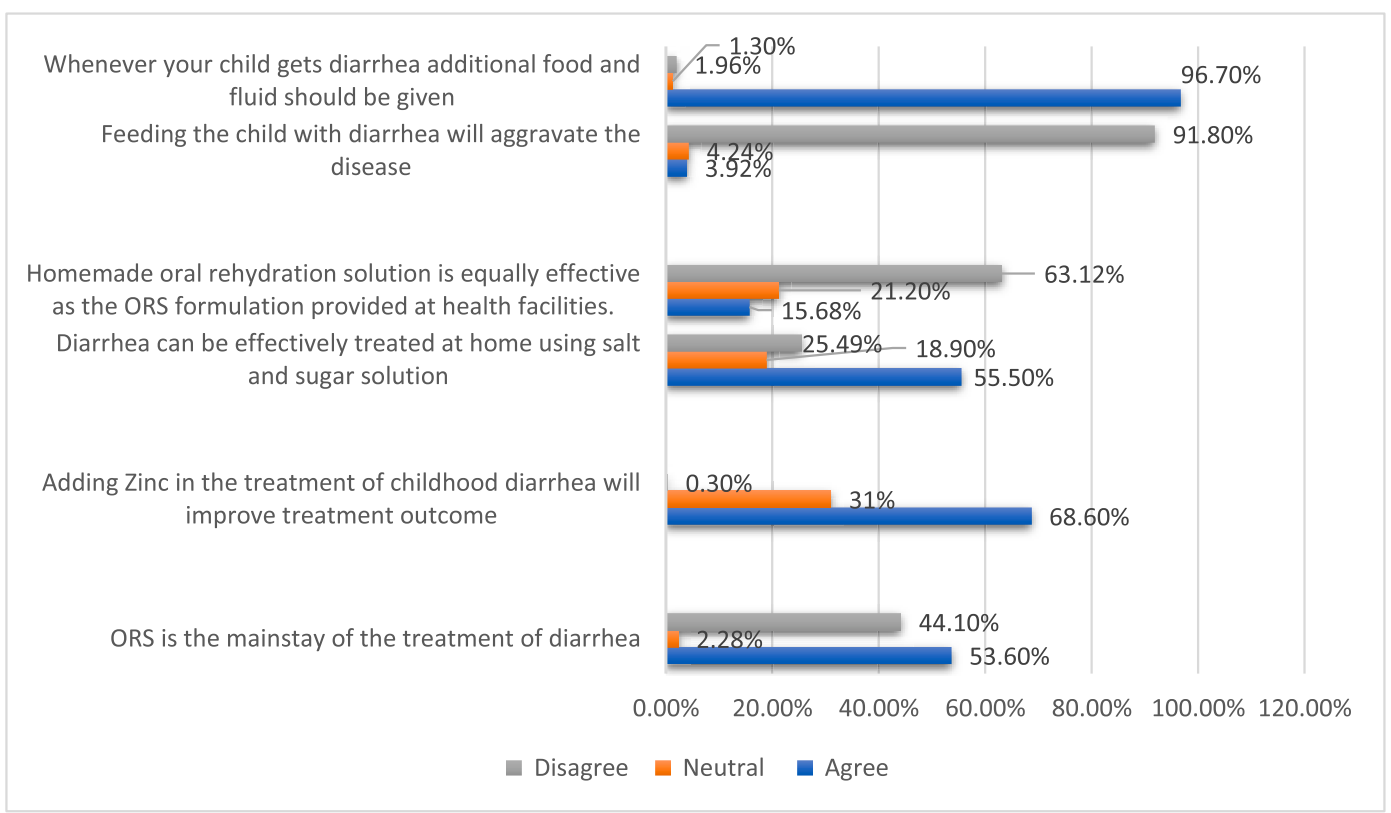

Fig. 1. Attitude of caregivers towards Oral Rehydration Salt (ORS) and zinc use for diarrheal disease management in under-five children in Gondar town, Amhara regional state, North West Ethiopia, 2021.

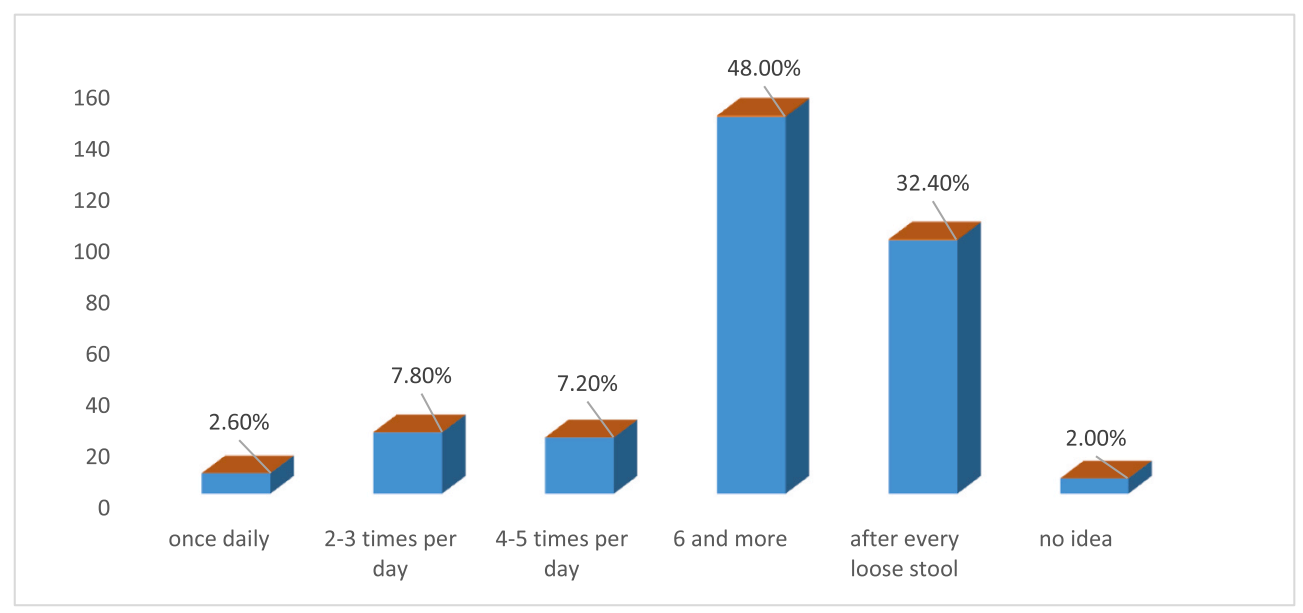

Fig. 2. Attitude of caregivers regarding the frequency of Oral Rehydration Salt (ORS) administration for management of diarrhea in under-five children in Gondar town, Amhara region, North West Ethiopia, 2021.

132.0)).

In the multivariable regression analysis, caregivers' educational status, occupational status, and sex were the significant factors associated with the knowledge of ORS and zinc usage in diarrheal disease management. Female caregivers were found 2.804 times more knowledgeable than males $(P=0.012)$. In addition, caregivers who have had higher education were 6.293 times more knowledgeable $(\mathrm{P}=0.049)$, and those employed caregivers were 2.313 times more knowledgeable $(\mathrm{P}=0.015)$ than their counterparts, respectively (Table 4).

\subsection{Factors associated with caregivers attitude towards ORS and zinc use in under-five children}

In the bivariate analysis, a significant association was observed between the educational status of caregivers and their attitude about ORS and zinc utilization for diarrheal disease case management. Caregivers with high school education, and with higher education (college, university level) were 4.872 and 4.148 times more likely to have a good attitude about ORS and zinc utilization, respectively than those who had no formal educations level $(\mathrm{COR}=4.872(1.212,19.591)),(\mathrm{COR}=4.148$ (1.065,16.154)). Similarly, employed caregivers were 2.144 times more likely to have a good attitude about ORS and zinc utilization than their counterparts (COR $=2.144(1.108,4.149)$ ) (Table 5).

In the multivariable regression analysis, however, only occupational status of the caregivers was significantly associated with their attitude. Employed caregivers were found to be 2.408 times more likely to have a good attitude about ORS and zinc utilization than unemployed respondents $(\mathrm{P}=0.041)$ (Table 5).

\subsection{Factors associated with care-givers practice towards use of ORS and zinc in under five children}

In the binary logistic regression analysis, there was a statistically significant association between caregivers' educational level, occupational status, family size, and sex with their practice on ORS and zinc usage for diarrhea management at a P-value of $\leq 0.05$. Caregivers with high school and higher education levels (Diploma, Degree) were 6.537 and 9.00 times more likely to have good practice compared with those 


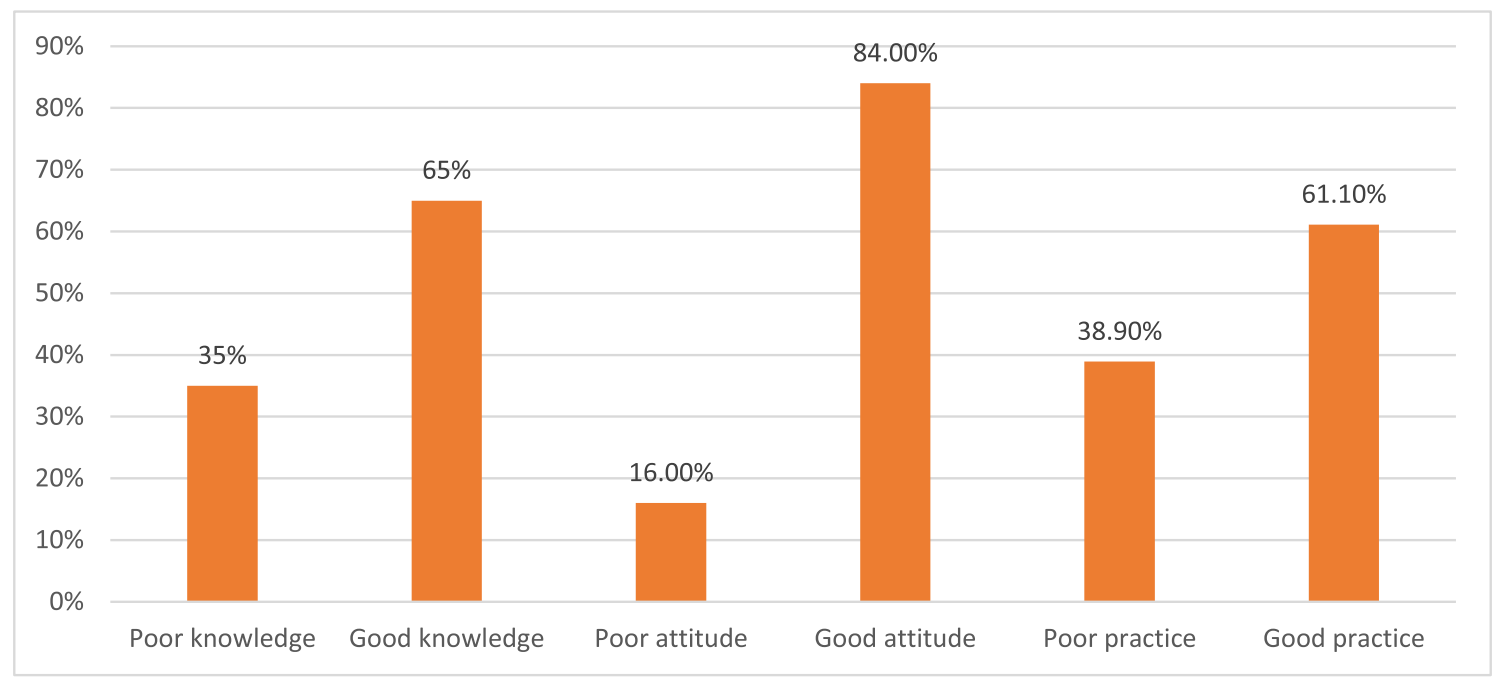

Fig. 3. KAP of Oral Rehydration Salt (ORS) and Zinc use for diarrheal disease management among caregivers of under-five children in Gondar town, Amhara regional state, North West Ethiopia, 2021.

Table 4

Association of the socio-demographic variables with knowledge of ORS and zinc usage in under-five children in Gondar town, Amhara regional state, North West Ethiopia, 2021.

\begin{tabular}{|c|c|c|c|c|c|c|c|c|}
\hline \multirow[t]{2}{*}{ Variables } & \multirow[t]{2}{*}{ ORS and $\mathrm{Zn}$ use } & \multicolumn{2}{|c|}{ Knowledge } & \multirow[t]{2}{*}{ Total } & \multirow[t]{2}{*}{ COR $(95 \% \mathrm{CI})$} & \multirow[t]{2}{*}{$\mathrm{P}$-value } & \multirow[t]{2}{*}{ AOR } & \multirow[t]{2}{*}{ P-value } \\
\hline & & Poor & Good & & & & & \\
\hline \multirow[t]{4}{*}{ Educational level } & No formal education & 8 & 2 & 10 & 1 & 1 & 1 & 1 \\
\hline & Primary school & 30 & 28 & 58 & $3.250(0.634,16.648)$ & 0.157 & $2.547(0.416,15.585)$ & 0.312 \\
\hline & High school & 41 & 67 & 108 & $7.676(1.55,38.004)$ & 0.013 & $4.234(0.699,25.651)$ & 0.116 \\
\hline & Higher education & 40 & 90 & 130 & $13.3(2.686,66.193)$ & 0.002 & $6.293(1.006,39.357)$ & 0.049 \\
\hline \multirow[t]{2}{*}{ Residence } & Rural & 16 & 14 & 30 & 1 & 1 & 1 & 1 \\
\hline & Urban & 103 & 173 & 276 & $1.722(0.806,3.680)$ & 0.161 & $1.450(0.613,3.430)$ & 0.397 \\
\hline \multirow[t]{3}{*}{ Occupational status } & Employed & 43 & 117 & 160 & $2.949(1.759,4.943)$ & 0.001 & $2.313(1.180,4.533)$ & 0.015 \\
\hline & Searching for job & 17 & 12 & 29 & $0.828(.367,1.868)$ & 0.649 & $0.654(.240,1.783)$ & 0.406 \\
\hline & House wife & 59 & 58 & 117 & 1 & 1 & 1 & 1 \\
\hline \multirow[t]{4}{*}{ Monthly income } & $<1000$ birr & 2 & 4 & 6 & 1 & 1 & 1 & 1 \\
\hline & 1000-3000birr & 34 & 26 & 60 & $3.571(0.393,32.476)$ & 0.258 & $4.092(0.387,43.216$ & 0.241 \\
\hline & 3000-5000birr & 24 & 46 & 70 & $14.444(1.580,132.0$ & 0.018 & $10.086(0.940,108.212$ & 0.056 \\
\hline & $>5000$ birr & 59 & 111 & 170 & $12.347(1.406,108.4)$ & 0.023 & 6.632(.636,69.202 & 0.114 \\
\hline \multirow[t]{3}{*}{ Family size } & $<$ or equal to 3 & 14 & 18 & 32 & 1 & 1 & 1 & 1 \\
\hline & 4 to 5 & 85 & 127 & 212 & $1.428(0.823,2.476)$ & 0.205 & $1.039(0.535,2.018)$ & 0.910 \\
\hline & $>5$ & 20 & 42 & 62 & $1.110(0.522,2.362)$ & 0.787 & $0.770(0.304,1.949)$ & 0.581 \\
\hline \multirow[t]{4}{*}{ Marital status } & Single & 2 & 6 & 8 & $4.500(0.408,49.654)$ & 0.219 & $9.475(0.456,196.942)$ & 0.146 \\
\hline & Married & 108 & 178 & 286 & $2.923(.480,17.709)$ & 0.244 & $1.918(0.198,18.567)$ & 0.574 \\
\hline & Divorced & 5 & 2 & 7 & $0.600(0.053,6.712)$ & 0.680 & $0.336(0.018,6.292)$ & 0.465 \\
\hline & Widowed & 4 & 1 & 5 & 1 & 1 & 1 & 1 \\
\hline \multirow[t]{3}{*}{ Age } & $15-24$ & 14 & 18 & 32 & 1 & 1 & 1 & 1 \\
\hline & $25-35$ & 85 & 127 & 212 & $0.612(0.254,1.473)$ & 0.274 & $0.377(0.125,1.135)$ & 0.083 \\
\hline & $>35$ & 20 & 42 & 62 & $0.907(.496,1.657)$ & 0.750 & $0.600(.275,1.309)$ & 0.199 \\
\hline \multirow[t]{2}{*}{ Sex } & Male & 21 & 29 & 50 & 1 & 1 & 1 & 1 \\
\hline & Female & 86 & 170 & 256 & $1.431(.771,2.657)$ & 0.256 & $2.804(1.254,6.270)$ & 0.012 \\
\hline
\end{tabular}

Abbreviations: AOR: Adjusted odds ratio, COR: Crude odds ratio, CI: Confidence interval, ORS: Oral Rehydration Salt, and Zn: Zinc.

that have no formal education, respectively $(\mathrm{COR}=6.537$ $(1.323,32294)),(\mathrm{COR}=9.000(1.829,44.29))$. Similarly, employed caregivers, those with a family size of $>5$, and female caregivers were $2.768,2.444$, and 1.288 times more likely to have a good practice than their counterparts, respectively (Table 6).

In the multivariable analysis, however, only occupational status of the caregiver and their sex were the only factors associated with their practice at $\mathrm{P} \leq 0.05$. Employed caregivers were 2.9 times more to have good practice than their unemployed counterparts $(\mathrm{AOR}=2.927$ (1.533,5.587). Similarly, female caregivers were found 2.8 times more practical about ORS and zinc utilization for management of diarrhea compared to males (AOR $=2.875(1.319,6.263)$ ) (Table 6).

\section{Discussion}

Diarrhea is a leading cause of morbidity and mortality in under-five children, particularly in developing nations. It is critical to treat diarrhea well before dehydration sets in. Millions of children's lives may be saved if caregivers were taught how to give their children ORS, Zinc, and proper home care. ${ }^{12}$ The cornerstone of fluid replacement is oral rehydration therapy. Proper awareness and administration of oral rehydration solution is one of the components of the WHO diarrhea control program. ${ }^{15,16}$

In the present study, 295(96.4\%) of the caregivers have had ever experienced ORS use. This finding is higher than a survey conducted in Wolaita sodo, in which $186(74.4 \%)$ of the caregivers experienced ORS use. ${ }^{11}$ This could be attributed to the difference in the prevalence rate of 
Table 5

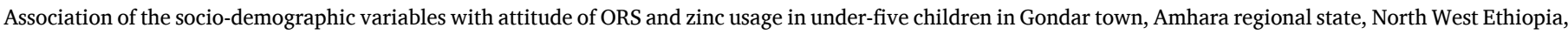
2021.

\begin{tabular}{|c|c|c|c|c|c|c|c|c|}
\hline \multirow[t]{2}{*}{ Variables } & \multirow[t]{2}{*}{ ORS and $\mathrm{Zn}$ use } & \multicolumn{2}{|c|}{ Attitude } & \multirow[t]{2}{*}{ Total } & \multirow[t]{2}{*}{ COR $(95 \% \mathrm{CI})$} & \multirow[t]{2}{*}{ p-value } & \multirow[t]{2}{*}{ AOR } & \multirow[t]{2}{*}{ P-value } \\
\hline & & Poor & Good & & & & & \\
\hline \multirow[t]{4}{*}{ Educational level } & No formal education & 4 & 6 & 10 & 1 & 1 & 1 & 1 \\
\hline & Primary school & 14 & 44 & 58 & $2.095(0.516,8.504)$ & 0.301 & $1.019(0.192,5.414)$ & 0.983 \\
\hline & High school & 13 & 95 & 108 & $4.872(1.212,19.591)$ & 0.026 & $2.093(0.382,11.472)$ & 0.395 \\
\hline & Higher education & 18 & 112 & 130 & $4.148(1.065,16.154)$ & 0.040 & $1.319(0.226,7.679)$ & 0.758 \\
\hline \multirow[t]{2}{*}{ Residence } & Rural & 4 & 26 & 30 & 1 & 1 & 1 & 1 \\
\hline & Urban & 45 & 231 & 276 & $0.790(0.263,2.373)$ & 0.674 & $0.719(0.221,2.338)$ & 0.583 \\
\hline \multirow[t]{3}{*}{ Occupational status } & Employed & 18 & 142 & 160 & $2.144(1.108,4.149)$ & 0.024 & $2.408(1.035,5.607)$ & 0.041 \\
\hline & Searching for job & 6 & 23 & 29 & $1.042(0.383,2.835)$ & 0.936 & $0.983(0.316,3.053)$ & 0.976 \\
\hline & House wife & 25 & 92 & 117 & 1 & 1 & 1 & 1 \\
\hline \multirow[t]{4}{*}{ Monthly income } & $<1000$ birr & 2 & 4 & 6 & 1 & 1 & 1 & 1 \\
\hline & 1000-3000birr & 13 & 47 & 60 & $1.808(0.297,10.992)$ & 0.520 & $2.775(0.351,21.946)$ & 0.333 \\
\hline & 3000-5000birr & 13 & 57 & 70 & $2.192(0.262,13.277)$ & 0.393 & $2.146(0.276,16.708)$ & 0.466 \\
\hline & $>5000$ birr & 21 & 149 & 170 & $3.548(0.612,20.575)$ & 0.158 & $3.401(0.455,25.443)$ & 0.233 \\
\hline \multirow[t]{3}{*}{ Family size } & $<$ or equal to 3 & 34 & 43 & 77 & 1 & 1 & 1 & 1 \\
\hline & 4 to 5 & 74 & 110 & 184 & $0.877(0.425,1.809)$ & 0.722 & $0.752(0.328,1.723)$ & 0.500 \\
\hline & $>5$ & 11 & 34 & 45 & $1.477(0.484,4.505)$ & 0.493 & $1.769(0.480,6.518)$ & 0.392 \\
\hline \multirow[t]{4}{*}{ Marital status } & Single & 0 & 8 & 8 & 242332 & 0.99 & 28621 & 0.99 \\
\hline & Married & 44 & 242 & 286 & $8.250(1.340,50.806)$ & 0.23 & $5.933(0.723,48.677)$ & 0.097 \\
\hline & Divorced & 2 & 5 & 7 & $3.750(0.331,42.467$ & 0.286 & $3.378(0.222,51.488)$ & 0.381 \\
\hline & Widowed & 3 & 2 & 5 & 1 & 1 & 1 & 1 \\
\hline \multirow[t]{3}{*}{ Age } & $15-24$ & 7 & 25 & 32 & 1 & 1 & 1 & 1 \\
\hline & $25-35$ & 28 & 184 & 212 & $1.840(0.728,4.652)$ & 0.198 & $1.914(0.684,5.358)$ & 0.216 \\
\hline & $>35$ & 14 & 48 & 62 & $0.960(0.343,2.684)$ & 0.938 & $1.044(0.291,3.740)$ & 0.948 \\
\hline \multirow[t]{2}{*}{ Sex } & Male & 9 & 41 & 50 & 1 & 1 & 1 & 1 \\
\hline & Female & 40 & 216 & 256 & $1.185(0.535,2.629)$ & 0.676 & $1.542(0.580,4.098)$ & 0.385 \\
\hline
\end{tabular}

Abbreviations: AOR: Adjusted odds ratio, COR: Crude odds ratio, CI: Confidence interval, ORS: Oral Rehydration Salt, and Zn: Zinc.

Table 6

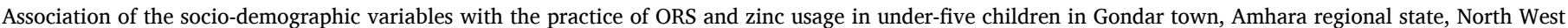
Ethiopia, 2021.

\begin{tabular}{|c|c|c|c|c|c|c|c|c|}
\hline \multirow[t]{2}{*}{ Variables } & \multirow[t]{2}{*}{ ORS and $\mathrm{Zn}$ use } & \multicolumn{2}{|c|}{ Practice } & \multirow[t]{2}{*}{ Total } & \multirow[t]{2}{*}{ COR $(95 \% \mathrm{CI})$} & \multirow[t]{2}{*}{$\mathrm{p}$-value } & \multirow[t]{2}{*}{ AOR } & \multirow[t]{2}{*}{ P-value } \\
\hline & & Poor & Good & & & & & \\
\hline \multirow[t]{4}{*}{ Educational level } & No formal education & 8 & 2 & 10 & 1 & 1 & 1 & 1 \\
\hline & Primary school & 30 & 28 & 58 & $3.733(0.729,19109)$ & 0.114 & $3.084(0.487,19.531)$ & 0.232 \\
\hline & High school & 41 & 67 & 108 & $6.537(1.323,32294)$ & 0.021 & $4.332(0.692,27.135)$ & 0.117 \\
\hline & Higher education & 40 & 90 & 130 & $9.000(1.829,44.29)$ & 0.007 & $5.183(0.796,33.747)$ & 0.085 \\
\hline \multirow[t]{2}{*}{ Residence } & Rural & 16 & 14 & 30 & 1 & 1 & 1 & 1 \\
\hline & Urban & 103 & 173 & 276 & $1.920(0.900,4.095)$ & 0.092 & $1.537(0.663,3.56)$ & $0.316)$ \\
\hline \multirow[t]{3}{*}{ Occupational status } & Employed & 43 & 117 & 160 & $2.768(1.673,4.579)$ & 0.001 & $2.927(1.533,5.587$ & 0.001 \\
\hline & Job seekers & 17 & 12 & 29 & $0.718(0.315,1.635)$ & 0.430 & $0.611(0.231,1.615)$ & 0.320 \\
\hline & House wife & 59 & 58 & 117 & 1 & 1 & 1 & 1 \\
\hline \multirow[t]{4}{*}{ Monthly income } & $<1000$ birr & 2 & 4 & 6 & 1 & 1 & 1 & 1 \\
\hline & 1000-3000birr & 34 & 26 & 60 & $0.382(0.065,2.250)$ & 0.288 & $0.422(0.062,2.860)$ & 0.377 \\
\hline & 3000-5000birr & 24 & 46 & 70 & $0.958(0.164,5.613)$ & 0.962 & $0.576(0.084,3.967)$ & 0.575 \\
\hline & $>$ 5000birr & 59 & 111 & 170 & $0.941(0.164,5.288)$ & 0.945 & $0.446(0.067,2.961)$ & 0.403 \\
\hline \multirow[t]{3}{*}{ Family size } & $<$ or equal to 3 & 34 & 43 & 77 & 1 & 1 & 1 & 1 \\
\hline & 4 to 5 & 74 & 110 & 184 & $1.175(0.686,2.012)$ & 0.556 & $0.900(0.479,1.694)$ & 0.745 \\
\hline & $>5$ & 11 & 34 & 45 & $2.444(1.082,5.522)$ & 0.032 & $2.103,0.805,5.496)$ & 0.129 \\
\hline \multirow[t]{4}{*}{ Marital status } & Single & 2 & 6 & 8 & $12.00(0.796,180.974)$ & 0.073 & $22.873(0.903,579.448)$ & 0.058 \\
\hline & Married & 108 & 178 & 286 & $6.593(0.727,59.755)$ & 0.094 & $9.461(0.664,134.719)$ & 0.097 \\
\hline & Divorced & 5 & 2 & 7 & $1.600(0.104,24.703)$ & 0.736 & $1.986(0.081,48.657)$ & 0.674 \\
\hline & Widowed & 4 & 1 & 5 & 1 & 1 & 1 & 1 \\
\hline \multirow[t]{3}{*}{ Age } & $15-24$ & 14 & 18 & 32 & 1 & 1 & 1 & 1 \\
\hline & $25-35$ & 85 & 127 & 212 & $1.162(0.549,2.461)$ & 0.695 & $1.105(0.478,2.556)$ & 0.816 \\
\hline & $>35$ & 20 & 42 & 62 & $1.633(0.679,3.931)$ & 0.274 & $1.957(0.664,5.766)$ & 0.223 \\
\hline \multirow[t]{2}{*}{ Sex } & Male & 22 & 28 & 50 & 1 & 1 & 1 & 1 \\
\hline & Female & 97 & 159 & 256 & $1.288(1.698,2.377)$ & 0.041 & $2.875(1.319,6.263)$ & 0.008 \\
\hline
\end{tabular}

Abbreviations: AOR: Adjusted odds ratio, COR: Crude odds ratio, CI: Confidence interval, ORS: Oral Rehydration Salt, and Zn: Zinc.

diarrheal disease in children between the two study areas.

In the present study, it was found that about $65 \%$ of the caregivers had good knowledge about ORS and zinc utilization for treating diarrhea. This result was greater than a study done in Botswana in which only $32 \%$ of the caregivers were reported to have good knowledge. ${ }^{17} \mathrm{~A}$ study done in Nigeria also showed that about $69.3 \%$ of mothers knew about ORS use and only $18.5 \%$ of caregivers had heard of Zinc use in diarrhea. $^{9}$

In this study, female caregivers were found 2.804 times more knowledgeable about ORS and zinc utilization than male counterparts. This could be due to the frequent involvement of females (usually mothers) in the care of their children when they were sick and this could increase the chance that they will be more exposed to health education and medical information as compared to male counterparts (fathers). In 
addition, caregivers who have had higher education and those employed were 6.293 and 2.313 times more knowledgeable than their counterparts, respectively.

This study also revealed that $84 \%$ of the participants had a good attitude towards ORS and zinc usage which is higher than a study done in wolaita sodo town, 76.8\%. ${ }^{11}$ Caregivers' employment status was also a significant factor associated with their attitude towards ORS and Zinc utilization in which employed caregivers were found to be 2.408 times more likely to have good attitude about ORS and zinc utilization than unemployed respondents. This could be due to the fact that employed caregivers would have better knowledge and access to medical information during their study times and/or at their workplaces which will have a direct influence to their overall health-related knowledge, attitude and practice.

Employed caregivers were also found 2.9 times more likely to have good ORS and Zinc usage practice than their unemployed counterparts. Similarly, female caregivers were found 2.8 times more practical about ORS and zinc utilization for management of diarrhea compared to males. This could be because of the fact that female caregivers (mostly mothers) are naturally very caring to their children's health and will most likely follow medical instructions in the care for their children.

In this study, about $94.1 \%$ of the caregivers followed the correct procedures in the preparation of ORS solution. This finding was greater than other studies done in Diredawa (85.4\%), and India (76.7\%). ${ }^{13,14}$ This could be justified by differences in educational status/awareness level of participants in these studies, and or frequent education by health workers in the present area due to the high prevalence of under-five diarrheal disease which will, in turn, increase caregivers' awareness of the care strategies.

In the present study, the majority $86.9 \%$ of the caregivers gain information about ORS and zinc utilization from health workers. A similar study conducted in Assela town, Ethiopia showed that (62.3\%) of the caregivers received their information about ORS and zinc utilization from the health workers. ${ }^{16}$ This could be due to frequent health facility visits and subsequent meetings with health professionals and/or the involvement of health extension workers that regularly provide home-based health education in these areas.

\subsection{Limitation of the study}

As the study is cross-sectional and depends on self-reported assessment, under-reporting is more likely to occur. It is possible that some caregivers may not remember the details about the usage and practice of ORS and Zinc (recall bias) which may affect the reliability and validity of the data.

\section{Conclusion}

There was good knowledge, attitude, and practice about Oral Rehydration Salt and zinc usage among child caregivers. Occupational status of caregivers was significantly associated with all three variables; knowledge, attitude, and practice. Regular educational strategies aimed at improving child caregivers' awareness of diarrhea disease management and utilization of ORS and Zinc tablets are advised.

\section{Ethical consideration}

Ethical clearance of the study was obtained from the ethical review board of the school of Pharmacy, the University of Gondar with an approval number of SOP/272/2013. Verbal consent was obtained from each participant. Participation in the study was on a voluntary basis, and participants were informed of their right not to participate in the study if they do not want to participate and the right to withdraw from the study at any point of the interview. Moreover, the confidentiality of the information was assured by using an anonymous questionnaire and keeping the data in a secured place.

\section{Availability of data and materials}

Most of the data is included in the manuscript. Additional can be found from the corresponding author based on reasonable request.

\section{Funding}

No funding to report.

\section{Declaration of competing interest}

The authors declares that they have no competing interests.

\section{Acknowledgment}

We would like to acknowledge University of Gondar for material supports.

\section{References}

1 Satcher D. Food safety: a growing global health problem. JAMA. 2000;283(14), 1817-1817.

2 Kotloff KL. The burden and etiology of diarrheal illness in developing countries. Pediatr Clin. 2017;64(4):799-814.

3 Olopha OO, Egbewale B. Awareness and knowledge of diarrhoeal home management among mothers of under-five in Ibadan, Nigeria. Univers J Publ Health. 2017;5(1): $40-45$.

4 Ogunrinde OGRT, Owolabi OA, Anigo KM. Knowledge, attitude and practice of home management of childhood diarrhoea among caregivers of under-5 children with diarrhoeal disease in Northwestern Nigeria. J Trop Pediatr. 2012;58(2):143-146. Journal of tropical pediatrics. 2012 Apr 1.

5 CSA I. Ethiopia Demographic and Health Survey, Central Statistics Agency and ICF International: USA, Addis Ababa, Ethiopia and Calverton. 2012. Maryland. 2011.

6 Lemma F, Matji J. Child nutrition in Ethiopia: a review article. Ethiop J Pediatr Child Health. 2014;10(10):1-15.

7 Blum LS, Oria PA, Olson CK, Breiman RF, Ram PK. Examining the use of oral rehydration salts and other oral rehydration therapy for childhood diarrhea in Kenya. Am J Trop Med Hyg. 2011;85(6):1126.

8 Mengistie B, Berhane Y, Worku A. Predictors of Oral Rehydration Therapy use among under-five children with diarrhea in Eastern Ethiopia: a community based case control study. BMC Publ Health. 2012;12(1):1-7.

9 Ugwu J, Ezeagu I, Ibegbu M. Awareness and practice of zinc therapy in diarrheal management among under-five caregivers in Enugu State, Nigeria. Int J Med Health Dev. 2019;24(2):63-69.

10 Kumar S, Subita L. Diarrhoeal diseases in developing countries: a situational analysis, Kathmandu Univ Med J. 2012;10(2):83-88.

11 Yasin Ddeky, Halala Y. Assessment of knowledge, attitude\& practice of child care givers towards oral rehydration salt for diarrhea treatment in under 5 children in wolaita sodo town, SNNPR/2016. Assessment. 2017;7(4).

12 Abera A, Assefa E. School of Nursing and Midwifery, Jimma University, Jimma, south west Ethiopia.

13 Workie Hm, Sharifabdilahi As, Addis Em. Mothers' knowledge, attitude and practice towards the prevention and home-based management of diarrheal disease among under-five children in Diredawa, Eastern Ethiopia, 2016: a cross-sectional study. BMC Pediatr. 2018;18(1):1-9.

14 Lamberti Lm, Fischer Walker Cl, Taneja S, Mazumder S, Black Re. The association between provider practice and knowledge of ORS and zinc supplementation for the treatment of childhood diarrhea in Bihar, Gujarat and Uttar Pradesh, India: a multisite cross-sectional study. PLoS One. 2015;10(6), e0130845.

15 Liben $\mathrm{Ml}$, Abebe $\mathrm{Y}$, Birara $\mathrm{S}$, et al. KNOWLEDGE, ATTITUDE AND PRACTICE TOWARDSORAL REHYDRATION SALTIN AYSAITA TOWN, AFAR REGIONAL STATE, NORTHEASTERN ETHIOPIA.

16 Adanech E. Assessment of Knowledge, Practice and Utilaization of Oral Rehayderation Therapy for Acute Watery Diarrhoeal Disease Case Management Among Mothers (Caregivers') of Under-five Children in Assela Town, Ethiopia. Addis Ababa University; 2015.

17 Mosweu GJ. Knowledge, Attitude and Practices of Caregivers (KAP) on Management of Childhood Diarrhoes Amond Children Aged between 0-5 Years Attending Child Welfare Clinic (CWC) in Mogoditshane Village. 2018. Botswana. 